\title{
Teknik Self Management dalam Pengelolan Strategi Waktu Kehidupan Pribadi Yang Efektif
}

\author{
Siska Novra Elvina \\ Universitas Islam Negeri (UIN) Sunan Kalijaga \\ siskanovra07@gmail.com
}

\begin{abstract}
This article describes all theories or aspects related to behavior counseling, self management techniques in time management. The research method used in this article is to use theoretical studies. Humans can only control time with activities that are carried out in the passage of time passed. Many people have realized that, but still often just pass the time. On the other hand, there are those who do not realize the time they have just missed. Behavior such as neglect of time that is passed away can be detrimental to every individual in carrying out their activities. Every behavior that has become a habit can be changed through the process of learning from the environment. Behavioral counseling is a model of counseling based on learning theory that focuses on individual behavior to help clients learn new behavior in solving problems. In implementing Behavior Counseling can use self management techniques. Self-management (self management) is a procedure where individuals regulate their own behavior. Based on the results that have been obtained, that every wrong behavior can be changed through behavior counseling using self management techniques. This research is very important, because we can learn how to manage time effectively so that the time we have does not go away.
\end{abstract}

Keywords: Counseling behavior, self management, adolescents

\begin{abstract}
Abstrak
Artikel ini memaparkan segala teori atau aspek yang terkait dengan konseling behavior, teknik self management dalam pengelolaan waktu. Metode penelitian yang digunakan dalam artikel ini adalah dengan menggunakan kajian teori. Manusia hanya dapat mengendalikan waktu dengan aktivitas yang diperbuat dalam perjalanan waktu yang dilalui. Banyak orang yang telah menyadari hal itu, tetapi masih sering melewatkan waktunya begitu saja. Dilain pihak, ada yang tidak
\end{abstract}


menyadari waktu yang sudah terlewatkan begitu saja. Prilaku seperti melalaikan waktu yang terlewat begitu saja dapat merugikan setiap individu dalam menjalankan aktivitasnya. Setiap tingkah laku yang sudah menjadi kebiasaan dapat diubah melalui proses belajar dari lingkungan. Konseling Behavioral adalah suatu model dalam konseling yang berlandaskan teori belajar berfokus pada tingkah laku individu untuk membantu klien mempelajari tingkah laku baru dalam memecahkan masalahnya. Dalam melaksanakan Konseling Behavior dapat menggunakan teknik self management. Pengelolaan diri (self management) adalah prosedur dimana individu mengatur perilakunya sendiri. Berdasarkan hasil yang sudah didapat, bahwasanya setiap prilaku yang salah dapat di ubah melalui konseling behavior menggunakan teknik self management. Penelitian ini sangat penting, karena kita dapat belajar bagaimana cara pengelolaan waktu yang efektif agar waktu yang dimiliki tidak berlalu begitu saja.

Kata Kunci: Konseling behavior, self management, remaja

\section{Pendahuluan}

Waktu adalah suatu roda yang selalu berputar, tidak pernah berputar kebelakang, selalu berputar kedepan dan tidak bisa dihentikan walau hanya satu detik. Waktu adalah sumber daya yang paling berharga yang kita miliki. Waktu tidak dapat disimpan di bank, tidak juga bisa dapat dibeli dengan apapun. Waktu merupakan kekayaan yang managerial yang tidak dapat dapat digantikan dan harus diperlakukan dengan kenyataan. Bila waktu hilang, maka musnah pula kehidupan kita.

Kesadaran akan waktu, dapat pula dilakukan dengan melihat betapa pendeknya usia kita. Hal ini mengandung arti, bahwa waktu yang tersedia sangat sedikit. Hal ini sama dengan, bahwa misi manusia memiliki masa yang terbatas, yaitu seusia hidup di dunia. Seharusnya, manusia mengatur waktunya dengan baik dan rapi, serta mengendalikan dan memanfaatkannya. Akan lebih baik lagi, jika ia mampu mengendalikan dan mengatur waktu secara konsisten, bukan malah dikendalikan dan diatur oleh waktu iu sendiri. Sehingga waktu yang berlalu dalam rentang usia, tidak terbuang percuma dan sia-sia. Untuk itulah, kesadaran penuh tentang pentingnya arti waktu sangat dibutuhkan. Adapun fakta dibalik waktu yang kita miliki adalah sebagai berikut $:^{1}$ (1) Waktu sudah ditetapkan dari-Nya. (a) 60 detik per menit (b) 60 menit per jam. (c) 24 jam per hari. (d) 86400 detik per hari. (2) Waktu terus berjalan dan tidak pernah berhenti.(3) Waktu tidak dapat diputar ulang. (4) Waktu tidak dapat disimpan dan dihemat.(5) Waktu tidak dapat dikurangi ataupun ditambah. 
Waktu memerlukan pengaturan dan pengelolaan. Jika kita dapat mengelola waktu dengan efesien berarti kita juga mengelola hidup dengan efektif. Saat mengatur waktu, sesungguhnya kita juga mengatur diri, pikiran, perasaan, dan kehendak kita untuk menjalani hidup. Pengaturan waktu yang efektif dapat dilakukan dengan cara belajar dari pengalaman mengenai waktuwaktu yang telah dilalui baik waktu yang dilewati secara pribadi maupun belajar dari waktu yang telah dilalui oleh orang lain.

Seseorang dalam usahanya untuk mencapai waktu yang efektif yang sesuai dengan keinginannya salah satunya dipengaruhi oleh pengelolaan diri (self management) yang dimiliki oleh masing-masing individu. Self Management merupakan upaya individu untuk melakukan perencanaan, pemusatan perhatian, dan evaluasi terhadap aktivitas yang dilakukan. ${ }^{2}$ Terdapat kekuatan psikologis yang memberi arah pada individu untuk mengambil keputusan dan menentukan pilihannya serta menetapkan cara-cara yang efektif dalam mencapai tujuannya. Self management meliputi pemantauan diri (self monitoring), reinforcement yang positif (self reward), kontrak atau perjanjian dengan diri sendiri (self contracting), dan penguasaan terhadap ransangan (stimulus control). ${ }^{3}$ Anggapan dasar self management merupakan teknik konseling behavior adalah setiap perilaku manusia itu merupakan hasil dari proses belajar (pengalaman) dalam merespon berbagai stimulus dari lingkungannya. Segenap perilaku manusia itu merupakan hasil dari proses belajar dalam merespons terhadap berbagai stimulus dari lingkungannya. ${ }^{4}$

Selain itu, self management merupakan salah satu teknik dalam konseling behavior, yang mempelajari tingkah laku (individu manusia) yang bertujuan merubah perilaku maladaptif menjadi adaptif. Self management adalah suatu prosedur dimana individu mengatur perilakunya sendiri. Dalam penerapan teknik self management tanggung jawab keberhasilan konseling berada di tangan klien. Konselor berperan sebagai pencetus gagasan, fasilitator yang membantu merancang program serta motivator bagi klien. ${ }^{5}$

Konseling Behavioral adalah teori konseling yang menekankan pada tingkah laku yang dikontrol oleh faktor-faktor dari luar. Manusia memulai kehidupannya dengan memberikan reaksi terhadap lingkungannya dan interaksi ini menghasilkan pola-pola perilaku yang kemudian membentuk kepribadian. Tingkah laku seseorang ditentukan oleh banyak dan macamnya penguatan yang diterima dalam situasi hidupnya. Teori Konseling Behavioral memiliki kelebihan

${ }^{2}$ Knowles, M.S. 2003. Self Directing Learning: A guide for learner and teachers. Chicago: Follet Publishing Company.

${ }^{3}$ Gunarsa, D. Singgih. 2004. Konseling dan Psikoterapi. Jakarta: Gunung Mulia.

${ }^{4}$ Insan Suwanto, Konseling Behavioral Dengan Teknik Self Management Untuk Membantu Kematangan Karir Siswa SMK Jurnal Bimbingan Konseling Indonesia Volume 1 Nomor 1 Maret 2016. Page 1-5 p-ISSN: 2477-5916 e-ISSN: 2477-8370

${ }^{5}$ Halimatus Sa'diyah ,dkk, Penerapan Teknik Self Management Untuk Mereduksi Agresifitas Remaja, Jurnal Ilmiah Counsellia, Volume 6 No. 2, November 2016:67 - 7 
dan kekurangan. Kelebihan dari Teori Konseling Behavioral merupakan suatu pendekatan terapi tingkah laku yang berkembang pesat dan sangat popular. Dikarenakan memenuhi prinsip-prinsip kesederhanaan, kepraktisan, kelogisan, mudah dipahami dan diterapkan, dapat didemontrasikan, menempatkan penghargaan khusus pada kebutuhan anak, serta adanya penekanan perhatian pada perilaku yang positif, sedangkan kekurangan dari teori. ${ }^{6}$

Meskipun konselor atau terapis behaviour menegaskan bahwa setiap klien adalah unik dan menuntut perilaku yang unik dan spesifik akan tetapi masalah salah satu klien sama dengan klien lainnya dan oleh karena tidak menuntut suatu strategi konseling atau terapi yang unik, perubahan klien hanya berupa gejala yang dapat meskipun konselor atau terapis Behaviour menegaskan bahwa setiap klien adalah unik dan menuntut perilaku yang unik dan spesifik akan tetapi masalah salah satu klien sama dengan klien lainnya dan oleh karena tidak menuntut suatu strategi konseling atau terapi yang unik, perubahan klien hanya berupa gejala yang dapat berpindah kepada bentuk perilaku yang lain.

Pada penelitian ini lebih berfokus kepada remaja karena remaja merupakan seseorang individu yang baru beranjak selangkah dewasa dan baru mengenal mana yang benar dan mana yang salah, mengenal lawan jenis, memahami peran dalam dunia sosial, menerima jati diri apa yang telah dianugerahkan Allah Subhanahu wa Ta'ala pada dirinya, dan mampu mengembangkan seluruh potensi yang ada dalam diri individu. Remaja saat ini dituntut harus siap dan mampu dalam menghadapi tantangan kehidupan dan pergaulan. Usia remaja adalah usia yang paling kritis dalam kehidupan seseorang, rentang usia peralihan dari masa kanak-kanak menuju remaja dan akan menentukan kematangan usia dewasa.

Pada usia remaja terjadi perubahan hormon, fisik, dan psikis yang berlangsung secara berangsur-angsur. Tahapan perkembangan remaja (adolescent) dibagi dalam 3 tahap yaitu early (awal), middle (madya), dan late (akhir). Masing-masing tahapan memiliki karakteristik dan tugastugas perkembangan yang harus dilalui oleh setiap individu agar perkembangan fisik dan psikis tumbuh dan berkembang secara matang, jika tugas perkembangan tidak dilewati dengan baik maka akan terjadi hambatan dan kegagalan dalam menjalani fase kehidupan selanjutnya yakni fase dewasa. Kematangan fisik dan psikis remaja sangat dipengaruhi oleh lingkungan keluarga yang sehat dan lingkungan masyarakat yang mendukung tumbuh kembang remaja ke arah yang positif. Jika pada masa remaja ini, seorang individu telah mampu untuk mengatur pribadinya dengan baik, maka akan berpengaruh baik dalam mengatur waktu selanjutnya.

${ }^{6} \mathrm{Ni}$ Luh Putu Indryaningsih, dkk Penerapan Teori Konseling Behavioral Dengan Teknik Self-Management Untuk MeningkatkanMotivasi Belajar Siswa Kelas Viii B4 Smp Negeri 4 Singaraja e-journal Undiksa Jurusan Bimbingan Konseling Volume: 2 No 1, Tahun 2014 
Fase remaja sangat berkaitan dunia sekolah yang selalu indah. Oleh sebab itu, artikel ini ditawarkan kepada Guru BK yang ada di Sekolah Menegah Atas (SMA) agar peserta didik mampu mengelola waktu dalam kehidupan pribadinya secara baik dan efektif. Tujuan dari penulisan ini untuk melihat sejauh mana peran Konseling Behavior dengan teknik self mangeement dapat merubah suatu individu (remaja) agar dapat menggunakan waktu dengan efektif dalam melakukan segala aktivitas sehari-hari.

\section{Hasil dan Pembahasan}

Bentuk Konseling Behavioral melalui teknik self management yang dirumuskan dalam studi literatur ini adalah konseling behavioral melalui teknik self management dalam mengelola waktu kehidupan pribadi yang efektif.

\section{Pengelolaan Waktu}

Sifat waktu pada hakikatnya, waktu yang berlalu dihadapan manusia mempunyai sifat-sifat inti, yang tidak dapat dikendalikan dengan kekuatan super mana pun. Diantara sifat waktu tersebut adalah: ${ }^{7}$ (1) Cepat Berlalu,waktu yang berjalan akan terasa begitu cepat berlalu. Seolah baru kemaren berlibur bersama keluarga, tak terasa sudah akan menghadapi hari minggu lagi. Rasanya baru saja melakukan suatu perbuatan, sekarang sudah melakukan perbuatan lainnya. Dulu masih anak-anak sekarang sudah mempunyai anak. (2) Memiliki kepercayaan yang berbeda; tergantung kondisi. Waktu yang berlalu mempunyai kapasitas kecepatan yang berbeda, menurut kondisi individu masing-masing. Namun demikian, sesungguhnya kecepatan waktu tersebut tetap. Contohnya, bagi Amim, satu jam sama saja dengan 60 menit, bagi Arief satu jam sama saja dengan 3600 detik, tidak ada perbedaan antara satu jam sama dengan 3600 detik, tidak ada perbedaan antara keduanya yang membedakan adalah kondisi invidu yang merasakan.(3) Tidak dapat digantikan, waktu yang telah berlalu, tidak dapat digantikan dengan waktu yang lain di masa yang akan datang. Waktu yang lalu tetaplah berlalu, sedang yang akan datang haruslah disongsong dengan perbuatan yang lebih baik. Satu hal yang tidak mungkin dalam hidup adalah kembali atau mengulang masa lalu. Hanya dalam angan dan khayal masa lalu dapat di putar kembali. Sebuah kemustahilan nyata, jika memaksakan diri untuk mengubah masa lalu. Hal yang dapat dilakukan hanyalah mengubah dari ini menjadi lebih baik dari hari kemaren. Karena pada hakikatnya, hari adalah masa lalu bagi masa depan. Setidaknya ketika merenungi hidup, disamping ada hal yang buruk, ada pula usaha untuk memperbaiki.

Strategi waktu, strategi merupakan suatu upaya yang didisiplinkan untuk membuat keputusan dan tindakan penting yang membentuk dan memandu

\footnotetext{
${ }^{7}$ Hendri Tanjung dan Nur Rohim Y, Management waktu 7 langkah membuat bidup penuh arti (Jakarta : AMZAH, 2015) h. 6-9
} 
bagaimana menjadi organisasi (atau entitas lainya), apa yang dikerjakan organisasi, dan mengapa organisasi mengerjakan seperti itu. ${ }^{8}$ Strategi di dalam management waktu sama dengan pengertian strategi secara umum. Strategi adalah suatu upaya yang dilakukan oleh seseorang dalam membuat keputusan dan tindakan penting untuk mencapai tujuan jangka panjang yang akan dicapai dari waktu yang dimilikinya.

Mengatur strategi waktu secara rapi dan efektif bukanlah pekerjaan yang mudah apalagi berupaya untuk mentaatinya secara konsisten. Sebagai anak muda dan mahasiswa anda pasti akan memiliki sekian banyak kegiatan dan tantangan baru, peran dan sekaligus tanggung jawab serta prioritas lain yang harus anda lakukan. Semua kegiatan dan tuntutan itu akan selalu bersaing merebut waktu dan perhatian anda. Contohnya, masa adaptasi dari masa remaja yang sebelumnya menjalani pendidikan menengah ke masa dewasa muda yang mulai merintis pendidikan tinggi di perguruan tinggi membuat dan menuntut terjadinya perubahan besar di dalam menata management waktu yang ada pada diri seseorang.Proses perencanaan strategi dapat dilihat melalui bagan berikut ini. $^{9}$

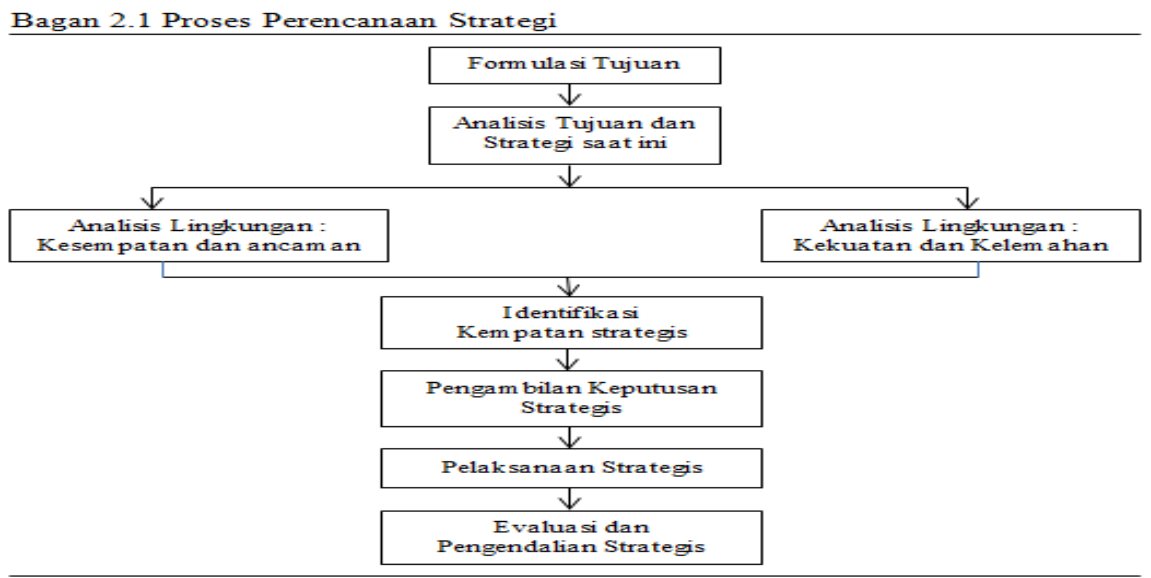

Proses management strategi ditandai dengan usaha mencapai tujuan melalui strategi dan kebijakan tertentu. Dengan demikian langkah pertama adalah penetapan tujuan. Langkah kedua adalah penetapan strategi untuk mencapai tujuan tersebut. Pelaksanaan strategi kemudian bergeser menjadi persoalan administatif. Manajer berurusan dengan pelaksanaan strategi seperti reaksi anggota organisasi, dan poltik pelaksanaan strategi. Langkah terakhir adalah pengendalian strategi yang memberikan umpan balik mengenai kemajuan yang dicapai dalam pelaksanaan strategi tersebut. Proses dalam menetapkan strategi sangatlah penting. Jika dikaitkan dengan waktu, proses dalam

${ }^{8}$ John M. Bryson, Perencanaan strategi bagi organisasi Soisal, (Yogyakarta : Purtaka pelajar \{anggota IKAPI\}, 2000) h.4-5

${ }^{9}$ Mamduh M. Hanafi, op.cit., h.135 
pembentukan strategi dalam membuat managementt waktu menjadi suatu hal yang pokok. Waktu memerlukan strategi dalam menggunakannya jika kita bisa mengelola strategi waktu dengan efesien berarti kita juga mampu mengelola hidup kita dengan efektif. ${ }^{10}$

Pengelolaan Waktu yang efektif, pengelolaan waktu adalah suatu cara yang dapat di lakukan untuk menyeimbangkan waktu untuk kegiatan belajar atau bekerja, bersenang-senang atau bersantai, dan beristirahat secara efektif. Tanpa disadari, setiap saat sesungguhnya telah membuat beberapa putusan terkait management waktu. Contohnya, ketika memutuskan kapan akan ke kampus, belajar di rumah, berolah raga, beribadah, mengunjungi perpustakaan, bersantai, berdiskusi dengan teman, berbelanja, dll. Semua putusan ini berperan penting di dalam penyusunan strategi management waktu. Hal ini juga dapat menjadikan seseorang untuk efektif sekaligus dalam beberapa hal. Dan sudah tentu, pengaturan kebijakan waktu ini akan dapat memastikan bahwa kita sudah menggunakan waktu terbaik secara efektif, hanya untuk tugas-tugas yang prioritas, dan membiarkan kegiatan-kegiatan rutin lainnya dilaksanakan pada saat yang telah di jadwalkan. ${ }^{11}$

Mengatur waktu secara rapi dan efektif bukanlah pekerjaan yang mudah apalagi berupaya untuk mentaatinya secara konsisten. Ada beberapa cara management waktu untuk kehidupan pribadi yang efektif, diantaranya : (1) Memiliki Visi, visi merupakan target akhir yang ingin dicapai dari suatu tindakan yang akan dikerjakan. ${ }^{12}$ Seseorang yang memiliki visi, harus memiliki peran yang terbaik untuk masa depannya. Misalnya, seseorang yang mempunyai keinginan untuk menjadi pengusaha, ia memiliki target agar tujuannya yang diharapkan tercapai. (2) Fokuskan Perhatian, fokus artinya memusatkan perhatian pada tugas atau tanggung jawab, atau pekarjaan yang ada dihadapan kita, serta berusaha melaksanakannya secara teru-menerus, sampai tujuan akhir tercapai. ${ }^{13}$ Fokus mencakup berbagai keahlian khusus, seperti kemampuan menguasai diri, menentukan sejumlah prioritas dan mengetahui perinciannya secara detail. Selain itu, dibutuhkan juga keahlian lain, seperti kemampuan mengatur, melanjutkan dan melaksanakan kegiatan. (3) Tentukan prioritas, banyak orang yang tidak bisa mengatur waktunya, karena tidak tahu mana yang penting dan mana yang tidak penting. Bahkan sebahagian dari kita, menganggap semua hal penting sehingga merasa bingung untuk menentukan hal apa yang harus dikerjakan terlebih dahulu. Orang yang menganggap semua hal penting, merasa bahwa waktu yang dimilikinya sedikit dan kurang, sehingga banyak kegiatan yang tidak dapat dikerjakan. Oleh karena itu, agar waktu yang dimiliki tertata rapi hal yang 2011) h. 234

${ }^{10}$ Khamdan, dkk, Studi al-Qur'an teori dan metodelogi (Yogyakarta : Idea Pres Yogyakarta,

${ }^{11}$ Harold L. Taylor, Management waktu (Tanggerang : Binarupa Aksara, 2010) h.58-59

${ }^{12}$ Hendri Tanjung dan Nur Rohim Y, op.cit., h. 27

${ }^{13}$ Hendri Tanjung dan Nur Rohim Y, Ibid., h. 29 
harusnya dilakuakan adalah menentukan prioritas. Urutan dalam menentukan prioritas dapat dibedakan menjadi paling penting, lebih penting, penting, kurang pening dan tidak penting. Ada beberapa cara dalam menentukan prioritas, diantaranya: ${ }^{14}$ (a) Tinjaulah kembali dan prioritaskan aktivitas menurut jangka waktunya, apakah jangka pendek atau jangka panjang. (b) Tulis tugas dan pekerjaan sehari-hari yang perlu dilakukan dengan urutan kepentingan dan tingkat kemendesakan. Semakin besar tingkat kepentingan dan kemendesakannya, semakin tinggi tingkat kemendesakannya. (c) Tulis semua hal yang akan diselesaikan, termasuk aktivitas pribadi, seperti bertelepon yang direncanakan dan waktu pribadi lainnya. (d) Lakukan tugas dan pekerjaan mulai dari yang teratas setiap hari dan bekerjalah terus kebawah hingga daftar terbawah. (e) Selalu periksa batas waktu untuk menetapkan situasi yan sebenarnya. (f) Berkatalah didalam diri bahwa kerjaan ini harus selesai hari ini, atau paling lambat hari ini. (g) Selalu menggubakan kalender harian atau mingguan dan daftar pekerjaan sebagai pengingat. (h) Pastikan juga bahwa telah menyediakan waktu untuk melengkapi daftar pekerjaan dengan telah memperhitungkan waktu pribadi dan gangguan lainnya yang mungkin akan muncul. (4) Buatlah perencanaan, membuat perencanaan adalah mletakkan tujuan-tujuan dalam sebuah program kerja yang dapat dilaksanakan. Dengan kata lain, membuat perencanaan adalah memberikan gambaran yang jelas mengenai masa depan dan menentukan langkah-lamhkah yang efektif untuk sampai pada hal yang diinginkan. (5) Jangan Menunda Pekerjaan, kebiasaan menunda-nunda menimbulkan situasi dimana pekerjaan yang seharusnya diselesaikan malah dikesampingkan untuk menyelesaikan pekerjaan atau kegiatan lain yang tidak ada manfaatnya terhadap hasil pokok. ${ }^{15}$ Adapun beberapa cara agar terhindar dari menunda pekerjaan diantaranya. ${ }^{16}(a)$ Menyadari terlebih dahulu bahwa anda adalah seseorang yang memang sering menunda pekerjaan. (b) Mulailah disiplin dengan melakukan pencatatan hal kecil. (c) Tulislah alasan motivasional yang sanggup mendorng untuk menyelesaikan pekerjaan tersebut dengan segera. (d) Atasi penundaan lainnya dengan metode yang sama. Semakin sering mengatasinya, semakin kecil kemungkinan mengulang penundaan tersebut. (6) Evaluasi, setiap perencanaan yang telah dikerjakan memberikan dua pilihan yaitu berhasil dan gagal, tidak ada opsi ketiga yang berada ditengahtengah kedua hal tersbut. Evaluasi dapat dilakukan kapan saja, dimana saja, dan pada setiap pekerjaan dan tindakan apapun. (7) Komitmen, komitmen adalah perpaduan antara persistensi dan konsistensi. Sebuah komitmen harus dilandasi suatu ketekunan yang tinggi dan ketetapan hati untuk tetap melakukan suatu hal tersebut secara terus-menerus secara berkesinambungan. Artinya jika sudah menetapkan suatu tekad atau keinginan maka lakukanlah secara tekun dan terus-

${ }^{14}$ J.J Reza, op.cit., h.44-45

15Philip E. Atkinson, Management waktu yang efektif (Jakarta : Binarupa Aksara, 1990)

h.59

${ }^{16}$ J.J Reza, op.cit., h.19-20 
menerus. Jangan sampai orang dekat dan hal-hal kecil lain menjadi batu sandungan atau penghalang dalam melaksanakan suatu pekerjaan. Ada beberapa cara dalam mengatasi rasa bosan, diantaranya : (a) Melakukan refreshing. (b) Jangan paksakan diri. (c) Lakukan variasi. (d) Jangan menyendiri, bergabunglah bersama teman yang lain.

Pengelolaan waktu adalah management untuk diri sendiri yang berguna untuk mengatur waktu pribadi secara baik. Jika pengelolaan waktu baik, maka kita mempunyai waktu untuk melakukan segalanya. Jika management waktu buruk, maka waktu akan berlalu begitu lama untuk digunakan. Waktu akan menjadi sesuatu yang terbaik jika mengetahui apa yang harus dilakukan dengannya. Waktu akan terus berjalan dan bergantung kepada diri sendiri sebagai nahkodanya.

\section{Konseling Behavioral}

Konseling Behavioral adalah teori/ model konseling yang menekankan pada tingkah laku yang dikontrol oleh faktor-faktor dari luar. Manusia memulai kehidupannya dengan memberikan reaksi terhadap lingkungannya dan interaksi ini menghasilkan pola-pola perilaku yang kemudian membentuk kepribadian. Tingkah laku seseorang ditentukan oleh banyak dan macamnya penguatan yang diterima dalam situasi hidupnya. Teori Konseling Behavioral memiliki kelebihan dan kekurangan. Kelebihan dari Teori Konseling Behavioral adalah bahwa pendekatan behaviour therapy merupakan suatu pendekatan terapi tingkah laku yang berkembang pesat dan sangat popular. Dikarenakan memenuhi prinsipprinsip kesederhanaan, kepraktisan, kelogisan, mudah dipahami dan diterapkan, dapat didemontrasikan, menempatkan penghargaan khusus pada kebutuhan anak, serta adanya penekanan perhatian pada perilaku yang positif, sedangkan kekurangan dari teori konseling behavioral yaitu konseling atau teori behaviour bersifat dingin (kaku), kurang menyentuh aspek pribadi bersifat manipulatif,dan mengabaikan hubungan antar pribadi, lebih terkonsentrasi pada teknik, meskipun konseling atau terapi behaviour sering menyatakan persetujuan pada tujuan klien, akan tetapi pemilihan tujuan lebih sering ditentukan oleh konselor atau terapis, meskipun konselor atau terapis behaviour menegaskan bahwa setiap klien adalah unik dan menuntut perilaku yang unik dan spesifik akan tetapi masalah salah satu klien sama dengan klien lainnya dan oleh karena tidak menuntut suatu strategi konseling atau terapi yang unik, perubahan klien hanya berupa gejala yang dapat berpindah kepada bentuk perilaku yang lain. ${ }^{17}$

Dalam pandangan Behavioral, perilaku dibentuk berdasarkan hasil dari segenap pengalamannya yang berupa interaksi individu dengan lingkungan sekitarnya yang membentuk sebuah kepribadian seseorang. Sehingga dapat diubah dengan memanipulasi dan mengkreasikan kondisikondisi belajar.

\footnotetext{
${ }^{17} \mathrm{Ni}$ Luh Putu Indryaningsih , op.cit.,
} 
Kepribadian sesorang dengan yang lainnya berbeda-beda karena kenyataannya manusia memiliki pengalaman yang berbeda dalam kehidupannya. Dalam proses konseling, konselor berfungsi sebagai konsultan, penasehat, pemberi dukungan dan fasilitator. Konselor dalam pendekatan ini berfungsi sebagai guru, pengaruh dan ahli yang mendiagnosa tingkah laku yang maladiptif dan menentukan prosedur untuk mengatasi persoalan tingkah laku individu.

Para Konselor Behavioral memandang kelainan perilaku sebagai kebiasaan yang dipelajari. Perilaku dapat diubah dengan mengganti situasi positif yang direkayasa sehingga kelainan perilaku berubah menjadi positif. Modifikasi perilaku menyimpang melalui pengubahan situasi lingkungan positif yang direkayasa sehingga dapat menstimulus terjadinya perilaku positif. Perubahan perilaku harus diusahakan melalui proses belajar (learning) atau belajar kembali (relearning) yang berlangsung selama proses konseling. Proses konseling pada dasarnya juga dipandang sebagai proses belajar yang dimaksudkan belajar untuk bertingkah laku kearah yang lebih baik dengan bantuan konselor kemudian pada akhirnya klien dapat terbiasa dengan berperilaku yang adaptif meskipun tanpa dibimbing konselor terus-menerus. ${ }^{18}$ Berdasarkan penjelasan tersebut maka dapat disimpulkan Konseling Behavioral adalah suatu teknik dalam konseling yang berlandaskan teori belajar berfokus pada tingkah laku individu untuk membantu klien mempelajari tingkah laku baru dalam memecahkan masalahnya. Tujuan Konseling Behavioral yaitu : (1) Menciptakan perilaku baru. (2) Menghapus perilaku yang tidak sesuai. (3) Memperkuat dan mempertahankan perilaku yang diinginkan.

\section{Self Management}

Dalam bahasa Indonesia : self-management adalah suatu proses di mana klien mengubah perilaku mereka sendiri secara langsung dengan menggunakan satu strategi atau kombinasi beberapa strategi. Selanjutnya Nursalim, dkk, menyatakan pengelolaan diri adalah suatu proses dimana klien mengarahkan perubahan tingkah laku mereka sendiri, dengan menggunakan satu strategi atau kombinasi strategi dan berdasarkan kamus yang disusun self-management adalah menunjuk pada suatu teknik dalam terapi Kognitif Behavioral berlandaskan pada teori belajar yang dirancang untuk membantu para klien mengontrol dan mengubah tingkah lakunya sendiri ke arah tingkah laku yang lebih efektif, sering dipadukan dengan ganjar diri (self-reward). ${ }^{19}$

${ }^{18}$ W. S Winkel\& Sri Hastuti. 2006. BimbingandanKonseling di InstitusiPendidikan. Yogyakarta: Media Abadi

${ }^{19}$ Siti Zubaedah, Penerapan Strategi Self Management Dalam Meningkatkan Disiplin Anak Usia Dini (Studi Pada RA DWP UIN Sunan Kalijaga Yogyakarta) Universitas Islam Negeri Sunan Kalijaga Yogyakarta, Al-Athfal: Jurnal Pendidikan Anak ISSN Cetak : 2477-4715 Diterima : 12 September 2015 Vol. 1 (2),2015, ISSN Online : 2477-4189 Direvisi : 20 Oktober 2015 
Self management melibatkan pemantauan diri, penguatan yang positif, kontrak atau perjanjian dengan diri sendiri dan penguasaan terhadap rangsangan. Self management atau pengelolaan diri merupakan suatu strategi pengubahan perilaku yang bertujuan untuk mengarahkan perilaku seseorang dengan suatu teknik atau kombinasi teknik terapeutik. Self management berkenaan dengan kesadaran dan keterampilan un tuk mengatur keadaan sekitarnya yang mempengaruhi tingkah laku individu. ${ }^{20}$

Self management adalah suatu proses dimana klien mengarahkan sendiri pengubahan perilakunya dengan satu strategi atau gabungan strategi. Self management bertujuan untuk membantu konseli menyelesaikan masalah, teknik ini menekankan pada perubahan tingkah laku konseli yang dianggap merugikan orang lain. Self management merupakan upaya individu untuk melakukan perencanaan, pemusatan perhatian, dan evaluasi terhadap aktivitas yang dilakukan. Di dalamnya terdapat kekuatan psikologis yang memberi arah pada individu untuk mengambil keputusan dan menentukan pilihannya serta menetapkan cara-cara yan g efektif dalam mencapai tujuannya. Pada dasarnya, pengelolaan diri terjadi ketika seseorang terlibat dalam satu perilaku dan mengendalikan terjadinya perilaku lain (perilaku sasaran) dikemudian waktunya. Self management melibatkan adanya perilaku pengendali dan perilaku yang terkendali. Dalam perilaku pengendali melibatkan penerapan strategi pengelolaan diri dimana anteseden dan konsekuensi dari perilaku terget atau perilaku alternatif yang akan dimodifikasi. Self management merupakan serangkaian teknis untuk mengubah perilaku, pikiran, dan perasaan Berdasarkan uraian di atas, self management merupakan seperangkat prinsip atau prosedur yang meliputi pemantauan diri (self monitoring), reinforcement yang positif (self reward), perjanjian dengan diri sendiri (self contracting), penguasaan terhadap rangsangan (stimulus control) dan merupakan keterkaitan antara teknik cognitive, behavior, serta affective dengan susunan sistematis berdasarkan kaidah pendekatan cognitive behavior therapy, digunakan untuk meningkatkan keterampilan siswa dalam proses kematangan karir yang diharapkan. ${ }^{21}$

Adapun tahap-tahap dalam self management sebagai berikut: (1) Konseli mengidentifikasi dan mencatat sasaran perilaku dan mengontrol penyebab serta akibatnya. (2) Konseli mengidentifikasi perilaku yang diharapkan arah perubahannya. (3) Konseli menjelaskan kemungkinan strategi pengelolaan diri (self management). (4) Konseli memilih satu atau lebih strategi self management. (5) Konseli menyatakan secara verbal persetujuan untuk menggunakan strategi self management. (6) Konselor memberikan instruksi dan model strategi yang

${ }^{20}$ Fauzan, Lutfi. Modul Rancangan Konseling Individual. Malang: Depdikbud IKIP Malang, 1992.

${ }^{21}$ Insan Suwanto, Konseling Behavioral Dengan Teknik Self Management Untuk Membantu Kematangan Karir Siswa SMK, Jurnal Bimbingan Konseling Indonesia Volume 1 Nomor 1 Maret 2016. Page 1-5 p-ISSN: 2477-5916 e-ISSN: 2477-8370 
dipilih. (7) Konseli mengulang pemahaman strategi yang dipilih. (8) Konseli menggunakan strategi yang dipilih. (9) Konseli mencatat penggunaan strategi serta tingkat perilaku sasaran. (10) Data konseli diperiksa oleh konselor bersama konseli dan konseli melanjutkan atau membuat revisi program. (11) Membuat catatan dan penyajian data pada diri sendiri dan penguat demi kemajuan

\section{Remaja}

Salah satu periode dalam rentang kehidupan individu adalah masa remaja. Fase ini merupakan segmen kehidupan yang penting dalam siklus perkembangan individu, dan merupakan masa transisi yang dapat diarahkan pada perkembangan masa dewasa yang sehat. Masa remaja atau "adolescence" berasal dari bahasa latin "adolescere" yang berarti "tumbuh" menjadi dewasa". Apabila diartikan dalam konteks yang lebih luas, akan mencakup kematangan mental, emosional, sosial dan fisik. Masa remaja menurut Hurlock diartikan sebagai suatu masa transisi atau peralihan, yaitu periode dimana individu secara fisik maupun psikis berubah dari masa kanak-kanak ke masa dewasa. ${ }^{22}$

Psikolog G. Stanley Hall "adolescence is a time of "storm and stress". Artinya, remaja adalah masa yang penuh dengan "badai dan tekanan jiwa", yaitu masa di mana terjadi perubahan besar secara fisik, intelektual dan emosional pada seseorang yang menyebabkan kesedihan dan kebimbangan (konflik) pada yang bersangkutan, serta menimbulkan konflik dengan lingkungannya. Dalam hal ini, Sigmund Freud dan Erik Erikson meyakini bahwa perkembangan di masa remaja penuh dengan konflik. Menurut pandangan teori kedua, masa remaja bukanlah masa yang penuh dengan konflik seperti yang digambarkan oleh pandangan yang pertama. Banyak remaja yang mampu beradaptasi dengan baik terhadap perubahan yang terjadi pada dirinya, serta mampu beradaptasi dengan baik terhadap perubahan kebutuhan dan harapan dari orang tua dan masyarakatnya. Bila dikaji, kedua pandangan tersebut ada benarnya, namun sangat sedikit remaja yang mengalami kondisi yang benar-benar ekstrim seperti kedua pandangan tersebut (selalu penuh konflik atau selalu dapat beradaptasi dengan baik). Kebanyakan remaja mengalami kedua situasi tersebut (penuh konflik atau dapat beradaptasi dengan mulus) secara bergantian (fluktuatif).

Selanjutnya Monks, dkk membatasi masa remaja yang berkisar dari usia 12 sampai 21 tahun yakni sampai selesainya pertumbuhan fisik. Pada masa remaja ini individu mencapai pertumbuhan fisik yang maksimal, dan pada masa ini pula mencapai kematangan kemampuan reproduksi. Kematangan ini menyebabkan remaja mempunyai perhatian terhadap lawan jenisnya, dan remaja akan berusaha untuk memikat lawan jenisnya tersebut. Selain pertumbuhan fisik, pada masa ini akan terjadi juga perkembangan fungsi-fungsi psikologis yang ditandai dengan peningkatan kekuatan mental, kemampuan

${ }^{22}$ Hurlock, Elizabeth.B, Psikologi Perkembangan: Suatu pendekatan sepanjang rentang kehidupan (edisi kelima), (Jakarta: Erlangga,1993) 
berpikir, kemampuan dalam memahami, dan kemampuan dalam mengingat. Dengan adanya peningkatan dalam kemampuan tersebut maka remaja mempunyai perhatian terhadap lingkungan sosial dan intelektual. Dengan memperhatikan pengertian remaja yang dikemukakan diatas, dapat disimpulkan bahwa masa remaja merupakan suatu fase pertumbuhan dari anak yang belum matang menuju orang dewasa yang matang, suatu periode transisi secara biologis, psikologis, dan sosial. Perubahan ini terjadi dengan sangat cepat dan terkadang tanpa kita sadari. ${ }^{23}$

Rentang kehidupan masa remaja mempunyai ciri-ciri tertentu yang membedakannya dengan periode sebelumnya dan sesudahnya. Masa remaja ini, selalu merupakan masa-masa sulit bagi remaja maupun orangtuanya. Menurut Sidik Jatmika, kesulitan itu berangkat dari fenomena remaja sendiri dengan beberapa perilaku khusus; yakni: (1) Remaja mulai menyampaikan kebebasannya dan haknya untuk mengemukakan pendapatnya sendiri. Tidak terhindarkan, ini dapat menciptakan ketegangan dan perselisihan, dan bias menjauhkan remaja dari keluarganya. (2) Remaja lebih mudah dipengaruhi oleh teman-temannya daripada ketika mereka masih kanak-kanak. Ini berarti bahwa pengaruh orangtua semakin lemah. Anak remaja berperilaku dan mempunyai kesenangan yang berbeda bahkan bertentangan dengan perilaku dan kesenangan keluarga. Contoh-contoh yang umum adalah dalam hal mode pakaian, potongan rambut, kesenangan musik yang kesemuanya harus mutakhir. (3) Remaja mengalami perubahan fisik yang luar biasa, baik pertumbuhannya maupun seksualitasnya. Perasaan seksual yang mulai muncul bisa menakutkan, membingungkan dan menjadi sumber perasaan salah dan frustrasi. (4) Remaja sering menjadi terlalu percaya diri (over confidence) dan ini bersama-sama dengan emosinya yang biasanya meningkat, mengakibatkan sulit menerima nasihat dan pengarahan oangtua ${ }^{24}$

Salah satu periode dalam rentang kehidupan ialah (fase) remaja. Masa ini merupakan segmen kehidupan yang penting dalam siklus perkembangan individu, dan merupakan masa transisi yang dapat diarahkan kepada perkembangan masa dewasa yang sehat. Untuk dapat melakukan sosialisasi dengan baik, remaja harus menjalankan tugas-tugas perkembangan pada usinya dengan baik. Apabila tugas pekembangan sosial ini dapat dilakukan dengan baik, remaja tidak akan mengalami kesulitan dalam kehidupan sosialnya serta akan membawa kebahagiaan dan kesuksesan dalam menuntaskan tugas perkembangan untuk fase-fase berikutnya. Sebaliknya, manakala remaja gagal menjalankan tugas-tugas perkembangannya akan membawa akibat negatif dalam

${ }^{23}$ Miftahul Jannah Remaja Dan Tugas-Tugas Perkembangannya Dalam Islam Dosen Fakultas Psikologi Universitas Islam Negeri Ar-Raniry, Banda Aceh Jurnal Psikoislamedia Volume 1, Nomor 1, April 2016

${ }^{24}$ Sidik Jatmika, Genk Remaja, Anak Haram Sejarab ataukah Korban Globalisasi?,(Yogyakarta:Kanisius, 2010) 
kehidupan sosial fase-fase berikutnya, menyebabkan ketidakbahagiaan pada remaja yang bersangkutan, menimbulkan penolakan masyarakat, dan kesulitankesulitan dalam menuntaskan tugas-tugas perkembangan berikutnya. ${ }^{25}$

\section{Penutup}

Konseling adalah suatu proses pemberian bantuan kepada klien baik secara individu maupun kelompok yang dilakukan oleh seseorang yang profesional (konselor) yang bertujuan untuk mengentaskan permasalahan klien serta memandirikan klien dalam melakukan sesuatu hal dari KES-T menjadi KES. Dalam melakukan kegiatan konseling banyak teori konseling yang dapat digunakan. Salah satu teori konseling yang dipakai dalam pembahasan pada artikel ini adalah Konseling Behavior. Konseling Behavior sebuah teori yang dapat digunakan konselor dalam melaksanakan suatu proses konseling untuk memodifikasi prilaku. Dalam pandangan Behavioral, perilaku dibentuk berdasarkan hasil dari segenap pengalamannya yang berupa interaksi individu dengan lingkungan sekitarnya yang membentuk sebuah kepribadian seseorang. Sehingga dapat diubah dengan memanipulasi dan mengkreasikan kondisi belajar. Teknik yang digunakan pada literatur ini untuk menguatkan teori Konseling Behavior adalah teknik Self management. Teknik Self management merupakan suatu prosedur yang digunakan untuk mengarahkan atau mengatur tingkah lakunya sendiri, di mana sifat dari teknik ini bisa digunakan untuk mengurangi dan meningkatkan. Hal ini yang akan menjadi kajian dalam artikel ini. Ditemukan bahwa banyak pada diri manusia yag sering kali terjadi, bahwa masih sangat sulit mengatur waktu atau pengelolaan waktu kehidupan pribadi yang efektif. Rendahnya pengetahuan mengenai pengelolaan waktu akan menjadi faktor penghambat seseorang dalam menggunakan waktu yang ia meiliki secara efektif. Contohnya, ketika seseorang tidak menentukan waktu yang prioritas apa yang akan dikerjakannya. Banyak orang yang tidak bisa mengatur waktunya, karena tidak tahu mana yang penting dan mana yang tidak penting. Bahkan sebahagian dari kita, menganggap semua hal penting sehingga merasa bingung untuk menentukan hal apa yang harus dikerjakan terlebih dahulu. Orang yang menganggap semua hal penting, merasa bahwa waktu yang dimilikinya sedikit dan kurang, sehingga banyak kegiatan yang tidak dapat dikerjakan. Oleh sebab itu, untuk mengatasi permasalahan tentang pengelolaan waktu bagi seseorang, sangat perlu diberikan Konseling Behavior melalui teknik self management. Dengan adanya pembahasan ini, dapat merubah pola pengelolaan waktu bagi setiap individu yang efektif dalam menggunakan waktu yang dimiliki.

\footnotetext{
${ }^{25}$ Khamim Zarkasih Putro Memahami Ciri dan Tugas Perkembangan Masa Remaja Fakultas Ilmu Tarbiyah dan Keguruan (FITK) Universitas Islam Negeri Sunan Kalijaga, Indonesia APLIKASIA: Jurnal Aplikasi Ilmu-ilmu Agama Volume 17, Nomor 1, 2017
} 


\section{Bibliografi}

Fauzan, Lutfi. 1992, Modul Rancangan Konseling Individual. Malang: Depdikbud IKIP Malang

Gunarsa, D. Singgih. 2004. Konseling dan Psikoterapi. Jakarta: Gunung Mulia.

Halimatus Sa'diyah ,dkk, Penerapan Teknik Self Management Untuk Mereduksi Agresifitas Remaja, Jurnal Ilmiah $\quad$ Counsellia, Volume 6 No. 2, November $2016: 67-7$

Harold L. Taylor,2010, Management waktu, Tanggerang : Binarupa Aksara

Hendri Tanjung dan Nur Rohim Y, 2015, Management waktu 7 langkah membuat bidup penuh arti , Jakarta : AMZAH

Hurlock, Elizabeth.B, 1993, Psikologi Perkembangan: Suatu pendekatan sepanjang rentang kehidupan (edisi kelima), Jakarta: Erlangga

Insan Suwanto, Konseling Behavioral Dengan Teknik Self Management Untuk Membantu Kematangan Karir Siswa Smk Jurnal Bimbingan Konseling Indonesia Volume 1 Nomor 1 Maret 2016. Page 1-5 p-ISSN: 2477-5916 e-ISSN: $2477-8370$

Insan Suwanto, Konseling Behavioral Dengan Teknik Self Management Untuk Membantu Kematangan Karir Siswa SMK, Jurnal Bimbingan Konseling Indonesia Volume 1 Nomor 1 Maret 2016. Page 1-5 p-ISSN: 2477-5916 e-ISSN: $2477-8370$

J.J Reza,2010, Manage Your Time For Success, Yogyakarta : CV. Andi Offset

John M. Bryson, 2000, Perencanaan strategi bagi organisasi Soisal, Yogyakarta : Purtaka pelajar \{anggota IKAPI\}

Khamdan, dkk,2011, Studi al-Qur'an teori dan metodelogi, Yogyakarta : Idea Pres Yogyakarta

Khamim Zarkasih Putro Memahami Ciri dan Tugas Perkembangan Masa Remaja Fakultas Ilmu Tarbiyah dan Keguruan (FITK) Universitas Islam Negeri Sunan Kalijaga, Indonesia APLIKASIA: Jurnal Aplikasi Ilmu-ilmu Agama Volume 17, Nomor 1, 2017

Knowles, M.S. 2003. Self Directing Learning: A guide for learner and teachers. Chicago: Follet Publishing Company.

Miftahul Jannah Remaja Dan Tugas-Tugas Perkembangannya Dalam Islam Dosen Fakultas Psikologi Universitas Islam Negeri Ar-Raniry, Banda Aceh Jurnal Psikoislamedia Volume 1, Nomor 1, April 2016

Ni Luh Putu Indryaningsih, dkk Penerapan Teori Konseling Behavioral Dengan Teknik Self-Management Untuk Meningkatkan Motivasi 
138 | Islamic Counseling: Jurnal Bimbingan dan Konseling Islam, Vol. 3, No. 2, 2019

Belajar Siswa Kelas Viii B4 Smp Negeri 4 Singaraja e-journal Undiksa Jurusan Bimbingan Konseling Volume: 2 No 1, Tahun 2014

Philip E. Atkinson,1990, Management waktu yang efektif, Jakarta : Binarupa Aksara

Sidik Jatmika, 2010, Genk Remaja, Anak Haram Sejarah ataukah Korban Globalisasi?,Yogyakarta:Kanisius

Siti Zubaedah, Penerapan Strategi Self Management Dalam Meningkatkan Disiplin Anak Usia Dini (Studi Pada RA DWP UIN Sunan Kalijaga Yogyakarta) Universitas Islam Negeri Sunan Kalijaga Yogyakarta, AlAthfal: Jurnal Pendidikan Anak ISSN Cetak : 2477-4715 Diterima : 12 September 2015 Vol. 1 (2), 2015, ISSN Online : 2477-4189 Direvisi : 20 Oktober 2015

W. S Winkel \& Sri Hastuti. 2006. Bimbingan dan Konseling di Institusi Pendidikan. Yogyakarta: Media Abadi 